\title{
EXPERIMENTAL CHRONIC INTOXICATION OF CHICKENS WITH POLYCHLORINATED BIPHENYLS (DELOR 103)
}

\author{
R. HALOUZKA ${ }^{1}$, V. JURAJDA ${ }^{2}$ and Milada VÁVROVÁ ${ }^{3}$ \\ Department of Pathomorphology ${ }^{1}$, Clinic of Avian Diseases ${ }^{2}$, Department of Meat Hygiene \\ and Technology ${ }^{3}$, University of Veterinary and Pharmaceutical Sciences, 61242 Brno
}

Received February 26, 1993

\begin{abstract}
Halouzka, R., V. Jurajda and Milada Vávrová: Experimental Chronic Intoxication of Chickens with Polychlorinated Biphenyls (Delor 103). Acta vet. Brno, 62, 1993: 151- 157 .

The effect of long-term intake of feed contaminated with polychlorinated biphenyls (PCB) in the form of Delor 103, a technical preparation ( $42 \%$ chlorine), on the dynamics of development of the morphological changes in the organs of chickens was investigated in an in-vivo experiment.

Brown Hisex layer hybrid cockerels from a commercial flock were fed a feed

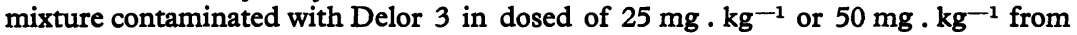
1 day to 10 weeks of age. At 2-week intervals they were weighed and sacrificed and relative mass of the bursa of Fabricius and spleen was determined. The lymphoid organs, liver, kidney, caecal valve, Harder's gland, oesophagus, gonads, skin and other grossly changed organs were subjected to histological examination. In evaluating the bursa of Fabricius, thymus and spleen use was also made of semiquantitative criteria. Pooled samples of the pectoral muscle were analysed for PCB content.

The alterations in the clinical status, body growth and relative mass of the bursa of Fabricius and spleen correlated with the dose level. Even the lower dose produced lymphocytotoxic, hepatotoxic and vascularotoxic effects. The changes observed at the end of the experiment corresponded to chronic intoxication with PCB. Of interest were the findings of adenoma of the pancreas and mainly dystrophic lesions in the central and peripheral nervous system.
\end{abstract}

Brown Hisex, chickens, PCB, organs, pathological changes

Polychlorinated biphenyls (PCB) are in consequence of their biological effects one of the causes of impairment of basic food products and foodstuffs of animal origin (Vávrová 1984). The main pathological changes found by a number of writers after intoxication with PCB in the organs of animals of various species including domestic fowls were included by Safe et al. (1987) in their monograph. In our country the effects of PCB on domestic fowls were studied by Herzig (1984, 1987), Lopuchovský (1986) and Košutzký (1987). A detailed description of the morphological changes in the organs of chickens after short-term intake of highly toxic PCB doses and after long-term intake of medium toxic PCB doses was presented in a previous report by $\mathrm{Ha}$ louzka et al. (1990).

The object of the present study was to identify morphological changes in the organs of experimental chickens after long-term administration of low PCB doses.

\section{Materials and Methods}

The experimental birds were Brown Hisex layer hybrid cockerels.

Delor 103 (produced by Chemko Strážské n. p.), a technical preparation containing polychlorinated biphenyls (PCB) and $42 \%$ chlorine, was dissolved in xylene so that $500 \mathrm{ml}$ of the solution contained $5 \mathrm{~g}$ Delor 103. 
After contamination with with $25 \mathrm{mg}$ (Group 1) and $50 \mathrm{mg}$ (Group 2) of Delor 103 per $\mathrm{kg}$ aeed mixture and after evaporation of xylene the feed mixture was fed to chickens between 1 day fnd 10 weeks of age ad libitum. Chickens fed the non-contaminated feed mixture served as controls (Group 3).

The chickens were observed regularly for clinical signs of disease and those that died or were sacrificed were subjected to pathomorphological examination. At two-week intervals 10 birds of each group were weighed, killed by decapitation and determination was made of relative mass of their bursa of Fabricius and spleen according to Lucio and Hitchner (1979).

Included in the study was examination of the sera for vitamin A and E levels and for antibody production in response to vaccination against Newcastle disease (Halouzka et al. 1993).

For histological examination tissue samples were taken from the lymphoid organs, liver, kidney, caecal valve, Harder's gland, oesophagus, testes, skin and other grossly changed organs. They were processed using the routine paraffin technique and stained with haematoxylin and eosin. In indicated cases further selective staining methods were used. Cytolytic changes in the lymphoid organs were evaluated semiquantitatively in immunosuppression degrees (Isd) and the index of immunosuppression (Is) was determined as described previously (Halouzka and Jurajda 1991).

Feed samples before and after contamination and pooled samples of the pectoral muscle of each group of chickens were examined for PCB content by gas chromatography (Vávrová 1984) at the given intervals.

The results were evaluated statistically by Student's t-test (Reisenauer 1965).

\section{Results}

The results of serological examination are presented in another report by Halouzka et al. (1993).

Control chickens showed no clinical signs of disease and no morphological changes in the organs.

In Group 2 some chickens showed reduced feed intake, apathy and fluffed feathers from the 5th post-hatching day. One bird died in the 5th week and 2 birds in the 6th week with signs of emaciation and anaemia. Post-mortem examination revealed hydropericardium, dystrophy of the liver and myocardium and marked atrophy of the lymphoid organs. In the 9th week 4 chickens began to limp, showing paresis to paralysis of the forelimbs and hindlimbs and opisthotonus. Two chickens died and 2 birds were sacrificed ante finem. Pathomorphological examination revealed emaciation, atrophy of the lymphoid organs, dystrophy of the liver and mild hydropericardium.

Body mass of the birds and relative mass of the bursa of Fabricius and spleen are presented in Table 1.

Before contamination PCB concentration of the feed was below the detectability level. After contamination it ranged between 0.056 and $1.458 \mathrm{mg} \mathrm{kg}^{-1}$ in Group 1 and between 1.831 and $3.574 \mathrm{mg} \cdot \mathrm{kg}^{-1}$ dry matter in Group 2. The PCB content of the muscles in the three groups of chickens at the given intervals is shown in Table 2. During the 8 weeks it increased 143 times in Group 1 and 135 times in Group 2.

Pathological examination revealed total plasmocyte and lymphocyte depletion in Harder's gland from the 4th week in Group 1 and from the 2nd week in Group 2 (Plate XXII., Fig. 1).

Steatosis, granular dystrophy, cholangial, pericholangial, vascular and perivascular necrotic foci in the liver were observed from the 4th week in both experimental groups. At the end of the experiment they were accompanied by proliferation of the bile ducts (Group 1) or progressed to portal fibrosis (Group 2) (Plate XXII., Fig. 2).

Examination of the pancreas revealed necrosis of the acini and cholangitis in 
both experimental groups (Plate XXIII., Fig. 3). At the end of the experiment adenomatous proliferation of the acini was diagnosed in one bird of Group 2 (Plate XXIII., Fig. 4).

Changes in the caecal valves, namely haemorrhages and cytolytic changes of various degrees, correlated with the size of the dose and were observed in both experimental groups from the 6th week. At the end of the experiment the degree

Table 1

Body mass (in $g$ ) and relative mass of the bursa of Fabricius and spleen of Brown Hisex chickens after administrattion of PCB (Delor 103)

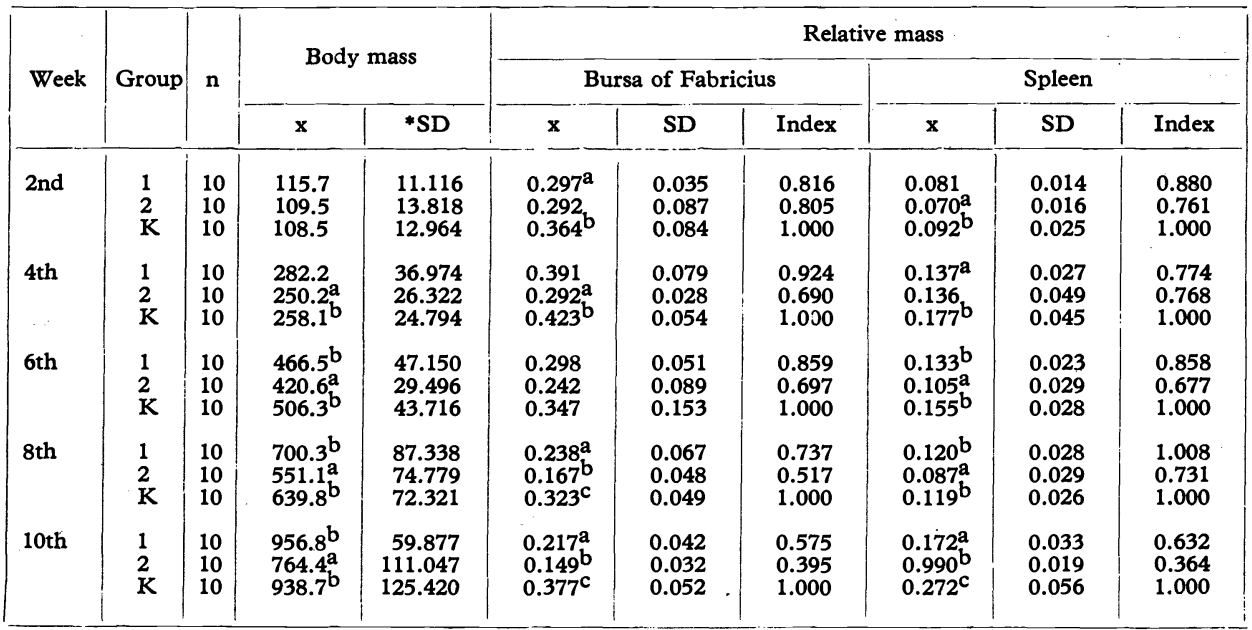

* - standard deviation

Groups designated with different letters differ in Student's test $(p \leq 0.05)$.

Table 2

PCB concentration in the pectoral muscle (mg. $\mathbf{k g}^{-1}$ fat proportion) of Brown Hisex chickens after administration of PCB (Delor 103)

\begin{tabular}{|c|c|c|c|c|}
\hline \multirow{2}{*}{ Week } & Group & $\mathrm{n}$ & Delor 103* & Delor 106* \\
\hline \multirow{2}{*}{ 2nd } & 1 & 10 & 0.041 & $\times$ \\
& 2 & 10 & 0.075 & $\times$ \\
4th & $\mathrm{C}$ & 10 & $\times$ & $\times$ \\
& 1 & 10 & 0.365 & $\times$ \\
& 2 & 10 & 0.820 & $\times$ \\
6th & $\mathrm{C}$ & 10 & $\times$ & $\times$ \\
& 1 & 10 & 1.715 & 0.0005 \\
& 2 & 10 & 3.650 & 0.0005 \\
8th & $\mathrm{C}$ & 10 & 0.001 & 0.0005 \\
& 1 & 10 & 4.003 & 0.0005 \\
& 2 & 10 & 8.170 & 0.0005 \\
10th & $\mathrm{C}$ & 10 & 0.001 & 0.0005 \\
& 1 & 10 & 5.843 & 0.0005 \\
& 2 & 10 & 10.127 & 0.0005 \\
\hline
\end{tabular}

* - related to Delor; $\times$ - below determinability level $(0.001 \mathrm{mg}$.

. $\mathrm{kg}^{-1}$ for Delor 103 and $0.0005 \mathrm{mg} . \mathrm{kg}^{-1}$ for Delor 106). 
of lymphocyte depletion in Group 2 chickens was characterized by total atrophy of the germinal centres and by diffuse atrophy of the lymphoid tissue with visualization of the stroma.

Conspicuous findings in the testes were degenerative changes in the spermiogenic epithelium from the 4th week; fibrosis of the testicular parenchyma at the end of the experiment was more intense in Group 2 chickens (Plate XXIV., Fig. 5).

Examination of the kidney revealed dystrophy of the proximal ducts, supprative changes, microlithiasis and fibrosis in both groups from the 6th week (Plate XXIV., Fig. 6).

In Group 2 chickens the skin was affected from the 8th week, showing sporadic degeneration and hyperplasia of feather follicle sheaths.

At the end of the experiment the findings included the absence of diffuse lymphoid tissue and germinal centres, and regressive vascular changes in the organs examined; a conspicuous finding in the spleen was the absence of ellipsoids in all the birds. Not rarely were observed chronic granulomatous lesions in various organs.

The cerebellum showed degenerative changes of Purkinje cells (Plate XXV., Fig. 7) and large neurons of cerebellar nuclei (Plate XXV., Fig. 8), and foci of demyelinization. Analogous changes were found in the medulla oblongata and lumbar medulla with occasional round-cell infiltration. A conspicuous finding was vasculopathy consisting in fibrinoid necrosis of the wall with intramural lymphoid cellulization. The nn. ischiadici and pl. brachialis showed interneuritic oedema and sporadic intraneural macrophagocytic and lymphoid cellulization.

Regressive changes in the lymphoid organs of sacrificed chickens are presented in Table 3.

Table 3

Morphological evaluation of immunosuppressive changes in the lymphoid organs of Brown Hisex chickens after administration of PCB (Delor 103)

\begin{tabular}{|c|c|c|c|c|c|c|c|c|c|c|c|}
\hline \multirow[b]{2}{*}{ 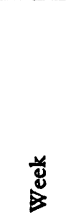 } & \multirow[b]{2}{*}{ 芯 } & \multirow[b]{2}{*}{ 垔 } & \multirow[b]{2}{*}{$\stackrel{*}{*}$} & \multirow[b]{2}{*}{ 蛋 } & \multirow[b]{2}{*}{ 莣 } & \multirow[b]{2}{*}{ 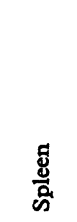 } & \multirow[b]{2}{*}{ \# } & \multicolumn{2}{|c|}{ Total } & \multicolumn{2}{|c|}{ Index lymph. org. } \\
\hline & & & & & & & & 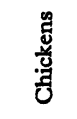 & 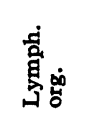 & 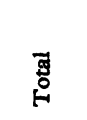 & $\star$ \\
\hline 2nd & $\begin{array}{l}1 \\
2\end{array}$ & $\begin{array}{r}* 0 / 10 \\
0 / 10\end{array}$ & $\begin{array}{l}0.0 \\
0.0\end{array}$ & $\begin{array}{l}0 / 10 \\
0 / 10\end{array}$ & $\begin{array}{l}0.0 \\
0.0\end{array}$ & $\begin{array}{l}0 / 10 \\
0 / 10\end{array}$ & $\begin{array}{l}0.0 \\
0.0\end{array}$ & $\begin{array}{l}0 / 10 \\
0 / 10\end{array}$ & $\begin{array}{l}0 / 30 \\
0 / 30\end{array}$ & $\begin{array}{l}0 / 30 \\
0 / 30\end{array}$ & $\begin{array}{l}0.00 \\
0.00\end{array}$ \\
\hline 4th & $\begin{array}{l}1 \\
2\end{array}$ & $\begin{array}{l}5 / 10 \\
8 / 10\end{array}$ & $\begin{array}{l}0.6 \\
2.0\end{array}$ & $\begin{array}{l}1 / 10 \\
1 / 10\end{array}$ & $\begin{array}{l}0.2 \\
0.1\end{array}$ & $\begin{array}{l}2 / 10 \\
8 / 10\end{array}$ & $\begin{array}{l}0.4 \\
1.5\end{array}$ & $\begin{array}{r}6 / 10 \\
10 / 10\end{array}$ & $\begin{array}{r}8 / 30 \\
17 / 30\end{array}$ & $\begin{array}{l}12 / 30 \\
36 / 30\end{array}$ & $\begin{array}{c}0.40 \\
1.20\end{array}$ \\
\hline 6th & $\begin{array}{l}1 \\
2\end{array}$ & $\begin{array}{r}5 / 10 \\
10 / 10\end{array}$ & $\begin{array}{l}0.9 \\
2.4\end{array}$ & $\begin{array}{l}2 / 10 \\
6 / 10\end{array}$ & $\begin{array}{l}0.3 \\
1.1\end{array}$ & $\begin{array}{l}3 / 10 \\
4 / 10\end{array}$ & $\begin{array}{l}0.6 \\
0.8\end{array}$ & $\begin{array}{r}5 / 10 \\
10 / 10\end{array}$ & $\begin{array}{l}10 / 30 \\
20 / 30\end{array}$ & $\begin{array}{l}18 / 30 \\
43 / 30\end{array}$ & $\begin{array}{l}0.60 \\
1.43\end{array}$ \\
\hline 8th & $\begin{array}{l}1 \\
2\end{array}$ & $\begin{array}{r}9 / 10 \\
10 / 10\end{array}$ & $\begin{array}{l}2.7 \\
3.2\end{array}$ & $\begin{array}{l}5 / 10 \\
4 / 10\end{array}$ & $\begin{array}{l}1.0 \\
1.1\end{array}$ & $\begin{array}{l}3 / 10 \\
5 / 10\end{array}$ & $\begin{array}{l}0.8 \\
1.5\end{array}$ & $\begin{array}{l}10 / 10 \\
10 / 10\end{array}$ & $\begin{array}{l}17 / 30 \\
29 / 30\end{array}$ & $\begin{array}{l}45 / 30 \\
58 / 30\end{array}$ & $\begin{array}{l}1.50 \\
1.93\end{array}$ \\
\hline 10th & $\begin{array}{l}1 \\
2\end{array}$ & $\begin{array}{r}9 / 10 \\
10 / 10\end{array}$ & $\begin{array}{l}2.3 \\
3.6\end{array}$ & $\begin{array}{r}8 / 10 \\
10 / 10\end{array}$ & $\begin{array}{l}2.3 \\
2.8\end{array}$ & $\begin{array}{r}8 / 10 \\
10 / 10\end{array}$ & $\begin{array}{l}2.2 \\
2.6\end{array}$ & $\begin{array}{r}9 / 10 \\
10 / 10\end{array}$ & $\begin{array}{l}24 / 30 \\
30 / 30\end{array}$ & $\begin{array}{l}68 / 30 \\
90 / 30\end{array}$ & $\begin{array}{l}2.26 \\
3.00\end{array}$ \\
\hline $\begin{array}{l}\text { Con- } \\
\text { trols }\end{array}$ & & $0 / 50$ & 0.0 & $0 / 50$ & 0.0 & $0 / 50$ & 0.0 & $0 / 50$ & $0 / 150$ & $0 / 150$ & 0.00 \\
\hline
\end{tabular}

* - No. positive/No. examined.

** - Mean index of immunosuppression. 
In Group 1 chickens morphological immunosuppressive changes in the bursa of Fabricius, thymus and spleen were found in $56 \%, 32 \%$ and $32 \%$ of the birds, the mean Is being $1.62,0.95$ and 1.0 , respectively.

In Group 2 chickens morphological immunosuppressive changes in the bursa of Fabricius, thymus and spleen were found in $76 \%, 42 \%$ and $54 \%$ of the birds, the mean Is being $2.6,1.02$ and 1.28 , respectively.

A total of 450 lymphoid organ specimens from experimental and control chickens were examined. In Group 1 and Group 2 morphological immunosuppressive changes were found in $39 \%$ and $64 \%$ of the specimens, respectively. In control chickens the findings were negative.

\section{Discussion}

The alterations in clinical status, body growth and relative mass of the bursa of Fabricius and spleen correlated with the dose of Delor 103, which is in keeping with the results reported in our previous studies (Halouzka et al. 1990; Halouzka and Jurajda 1992).

Whereas Group 1 chickens showed neither clinical signs of disease nor growth depression, Group 2 chickens exhibited growth depression from the 4th week and clinical signs of intoxication from the 6th week. The PCB concentration of the muscles in Group 2 chickens was about twice that found in Group 1 and is therefore the causative factor of growth depression. From our measurements it appears that $5.843 \mathrm{mg}$ PCB. $\mathrm{kg}^{-1}$ fat proportion of the muscles does not cause growth depression in Brown Hisex cockerels. In this respect no published data are available to us for comparison.

The morphological changes observed in the organs of the experimental birds corresponded to chronic intoxication with PCB in domestic fowls (Safe and Hutzinger 1987). No porphyrin deposits, however, were found, obviously because of the short duration of our experiment. The possible involvement of xylene in the doses of 5 and $2.5 \mathrm{ml} . \mathrm{k}^{-1}$ feed mixture in the aetiopathogenesis observed was excluded in our previous preliminary experiments (Halouzka and Jurajda 1988, unpublished observations).

An exceptional finding was the observation of adenomatous proliferation of the exocrine portion of the pancreas. In laboratory rodents the carcinogenity of PCB was demonstrated repeatedly after an almost year-long intake of low PCB doses (Kimbrough et al. 1975). In birds it has not been observed to date. The adenoma diagnosed in the present study is the first finding of its kind.

Another hitherto underscribed observation was the finding of nervous symptoms with marked morphological changes in the central and peripheral nervous system of sacrificed chickens and those that died. The causal pathogenesis of these changes is difficult to clarify with the methods used in our study. In chickens transient paralysis was reported as a rare manifestation of Marek's disease (Payne 1985; Swayne et al. 1989). Although infection with MDV and an over-all metabolic derangement (Halouzka et al. 1990, 1993) cannot be entirely excluded, we suppose that the changes observed by us rather suggest an autoimmune process induced by PCB-damaged myelin.

From our results it appears that long-term administration even of the lower PCB dose results in marked regressive changes in the central and peripheral lymphoid organs and produces hepatotoxic and vascularotoxic effects. The incidence 
of regressive changes in the lymphoid organs of both experimental groups showed a continuously increasing intensity till the end of the' experiment. The peripheral lymphoid tissue reacted to PCB in the same way as did the central lymphoid tissue. The paraocular and intestinal lymphoid tissue appeared to be considerably sensitive, which under natural conditions may have adverse effects on the defence capacity of the upper respiratory and intestinal tracts. Similar conclusions were reported by Davelaar and Kouwenhoven (1981).

The immunosuppressive effect of PCB (Delor 103) was demonstrated not only by the presence of suppurative lesions in the organs but also on the basis of serological evidence, namely by a marked depression in the production of antibodies against Newcastle disease after vaccination (Halouzka et al. 1993).

It can be concluded that the intake of PCB by chickens, even in doses that do not cause a depression of body growth, exerts an immunosuppressive effect and induces a variety of pathological changes in the organs including the nervous system.

\section{Experimentální chronická intoxikace kư̌at polychlorovanými bifenyly (Delor 103)}

$\mathrm{V}$ pokusu in vivo jsme sledovali vliv dlouhodobého př́ijmu krmiva kontaminovaného polychlorovanými bifenyly (PCB) ve formě technického přípravku Delor $103(42 \%$ chloru) na dynamiku rozvoje morfologických změn v orgánech kuřat.

Kohoutci nosného hybrida Hisex hnědý z komerčního chovu byli krmeni od 1. dne do 10. týdne věku krmnou směsí s přídavkem Deloru $103 \mathrm{v}$ dávkách 25 $\mathrm{mg} . \mathrm{kg}^{-1}$ nebo $50 \mathrm{mg} . \mathrm{kg}^{-1}$. Ve dvoutýdenních intervalech byla kuřata vážena, utrácena a stanovovali jsme relativni hmotnost Fabriciovy bursy a sleziny. Histologicky jsme vyšetřovali lymfatické orgány, játra, ledviny, cékální chlopeň, Harderovu žlázu, jícen, gonády, kủži a dalši makroskopicky změněné orgány. Při hodnocení Fabriciovy bursy, thymu a sleziny jsme použivali i semikvantitativní kritéria. Směsný vzorek prsní svaloviny byl analyzován na obsah PCB.

Alterace klinického stavu, růstu kuřat, relativní hmotnosti Fabriciovy bursy a sleziny byla $\mathrm{v}$ pozitivní korelaci s výši dávky. I nižši dávka se projevila lymfocytotoxicky, hepatotoxicky a vaskulárně toxicky. $\mathrm{Na}$ konci pokusu odpovídaly pozorované změny chronické intoxikaci $\mathrm{PCB}$. Zajímavým nálezem byl adenom pankreatu a převážně dystrofické léze centrálního a periferního nervového systému.

\section{Экспериментальная хроническая интоксикация цыплят полихлорированными дифенилами (Целор 103)}

В ходе эксперимента на живом организме проводили наблюдения длительного приема кормов, контаминированных полихлорилованными дифенилами (РСВ) в форме технического препарата Делор 103 (42\% хлора), на динамику развития морфологических изменений в органах цыплят.

Петүшков несущего гибрида Гисекс коричневый коммерческого птицеводства кормили с 1 по 10 сутки возраста смесью с добавлением Делора 103 дозой 25 мг.кг-1 или 50 мг.кг-1. В двухнедельных интервалах цыплят взвешивали, умерщвляли и определяли относительную массу 
фабрициевой сумки и селезенки. Проводили гистологические исследования лимфатических органов, печени, почек, цекальной заслонки, гердеровой железы, пищевода, ноловых желез, кожи и других макроскопичєски измененных органов. В ходе оценки фабрициевой сумки, випочковой железы и селезенки пользовались также полүколичественными критериями. Проводили анализ содержания РСВ смесьного образца грудной мышечной ткани.

Чередование клинического состояния, роста цыплят, относительной массы фабрициевой сумки и селезенки находилось в позитивной корреляции к более высокой дозе. Даже более низкая доза проявлялась лимфоцитотохсически, гепатотоксически и васкулярнотоксически. В конце эксперимента наблюдаемые изменения соответствовали хронической интоксикации РСВ. Интересным открытием оказалась аденома поджелудочной железы и преимүщественно дистрофические повреждения центральной и периферической нервной системы.

\section{References}

DAVELAAR, F. G. - KOUWENHOVEN, B.: Study on the local effect of eyedrop vaccination against Infectious brochitis in 1-day-old chicks with maternal antibodies. Avian Pathol., 10, 1981: $83-90$

HALOUZKA, R. - JURAJDA, V.: Morphological expression of immunosuppression in poultry. Acta vet. Brno, 60, 1991: 271-276

HALOUZKA, R.- JURAJDA, V.: Effect of polychlorinated biphenyls (PCB) on the infection of chickens with turkey herpesvirus THV-BIO-I. Acta vet. Brno, 61, 1992: 133-139

HALOUZKA, R. - JURAJDA, V.-MINKSOVA, E.: Vliv polychlorovaných bifenylů na humorální imunitu po vakcinaci proti Newcastleské nemoci a na koncentraci vitamínů $\mathrm{A}$ a $\mathbf{E}$ v krevním séru kư̌at. Acta vet. Brno, 1993 (in print)

HALOUZKA, R.-RUPRICH, J.-PISKAC, A.: Ưčinek polychlorovaných bifenylů (PCB) na organismus kuřat: patologické změny orgánů po krátkodobém a dlouhodobém přijmu vysokých dávek Deloru 103. Veter. Med. (Praha), 35, 1990: 303-312

HERZIG, I.: Nutriční faktory v etiologii edémové nemoci drůbeže. Project report, VÚVeL Brno $1984,42 \mathrm{p}$

HERZIG, I.: Cizorodé látky v krmivu. Bull. C̆SVTS VŠV Brno, 1, 1987: 1-22

KIMBROUGH, R. D. - SQUIRE, R. A. - LINDER, R. E. et al.: Induction of liver tumours in Sherman strain female rats by polychlorinated biphenyl Aroclor 1260. J. Natl. Cancer Inst., 55, 1975: $1453-1459$

KOSUTZKÝ, J.: Biologické a ekotoxikologické faktory $\mathrm{v}$ reprodukcii hydiny. Veterinárstvo, 2/87C, Bratislava, VEDA 1987: 433-438

LOPUCHOVSKÝ J.: Interakcia cholekalciferol a a polychlórovaným tifenylom (Delor 103) u hydiny. Biol. Chem. Vet., 22, 1986: 433-438

LUCIO, B. - HITCHNER, S. B.: Infectious bursal disease emulsified vaccine: effect upon neutralizing-antibody levels in the dam and subsequent protection of the progeny. Avian Dis., 23, 1979: $466-478$

PAYNE, L. N.: Pathology. In: Marek's disease. L. N. Payne ed., Martinus Nijhoff Publ. Boston 1985: $43-76$

REISENAUER, R.: Metody matematické statistiky a jejich aplikace. SNTL Práce, 1965, $196 \mathrm{p}$

SAFE, S. - HUTZINGER, O. et al.: Polychlorinated Biphenyls (PCBs): Mammalian and Environmental Toxicology. In: Environ. Toxin Ser. 1, Springer Verlag Berlin-Heidelberg 1987, $152 \mathrm{p}$

SWAYNE, D. E. - FLETCHER, O. J. - SCHIERMAN, L. W.: Marek's disease virus-induced transient paralysis in chickens. I. Time course association between clinical signs and histological brain lesions. Avian Pathol., 18, 1989: 385-396

VÁVROVÁ, M.: Stanovení reziduí polychlorovaných bifenylů v biologickém materiálu chromatografickými metodami. PhD thesis, VŠV Brno 1984, $138 \mathrm{p}$ 
Halouzka, R. et al.: Experimental Chronic Intoxication... pp. 151-157 Plate XXII.

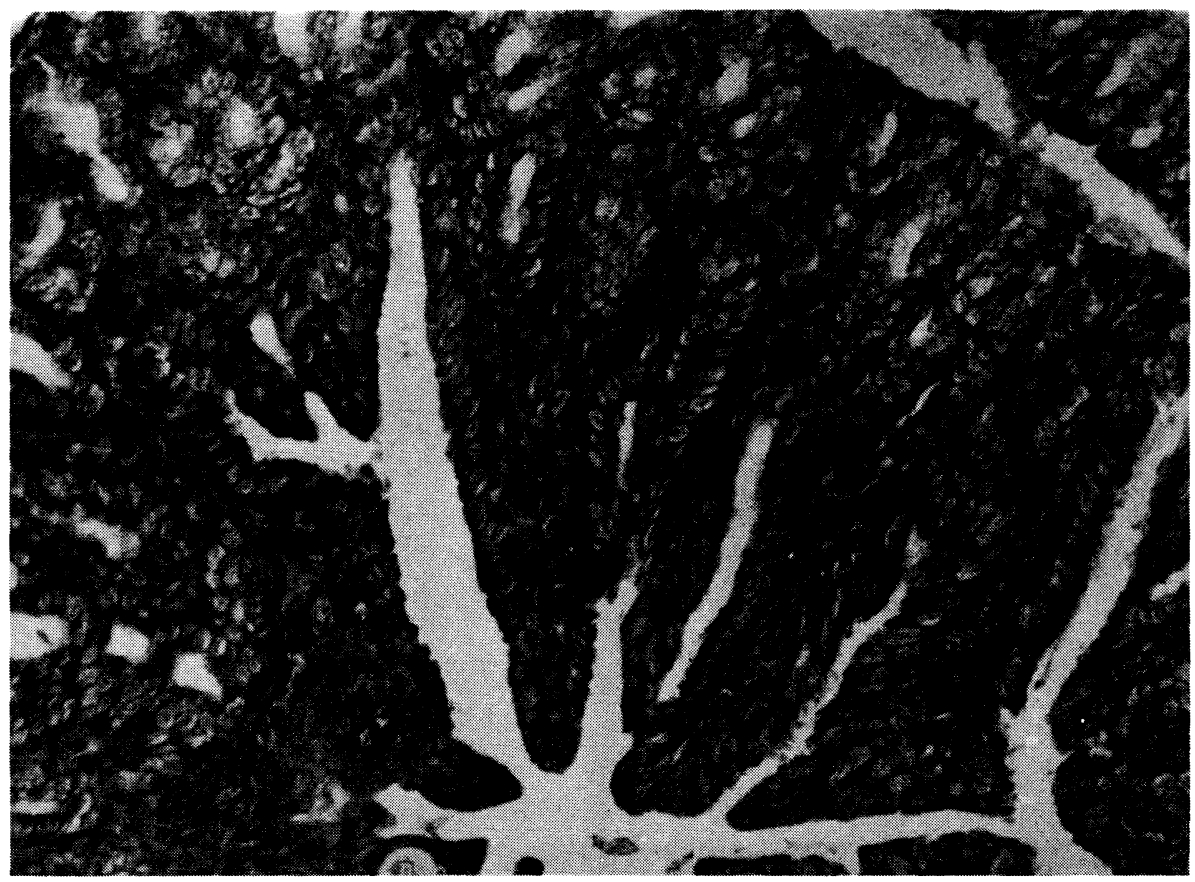

Fig. 1. Plasmocyte and lymphocyte depletion of Harder's gland HE; $\times 640$.

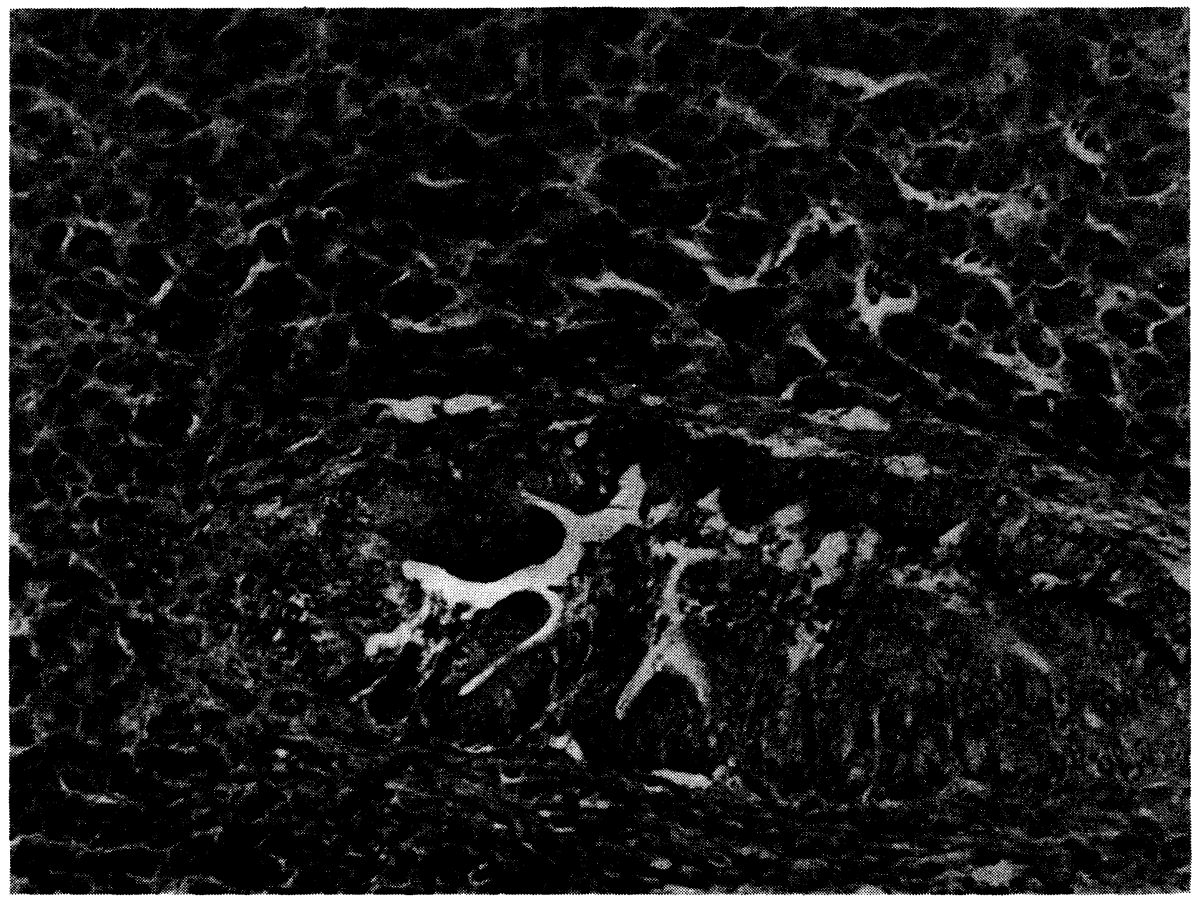

Fig. 2. Hyperplasia and proliferation of the gall-duct lining in the liver. HE; $\times 640$. 


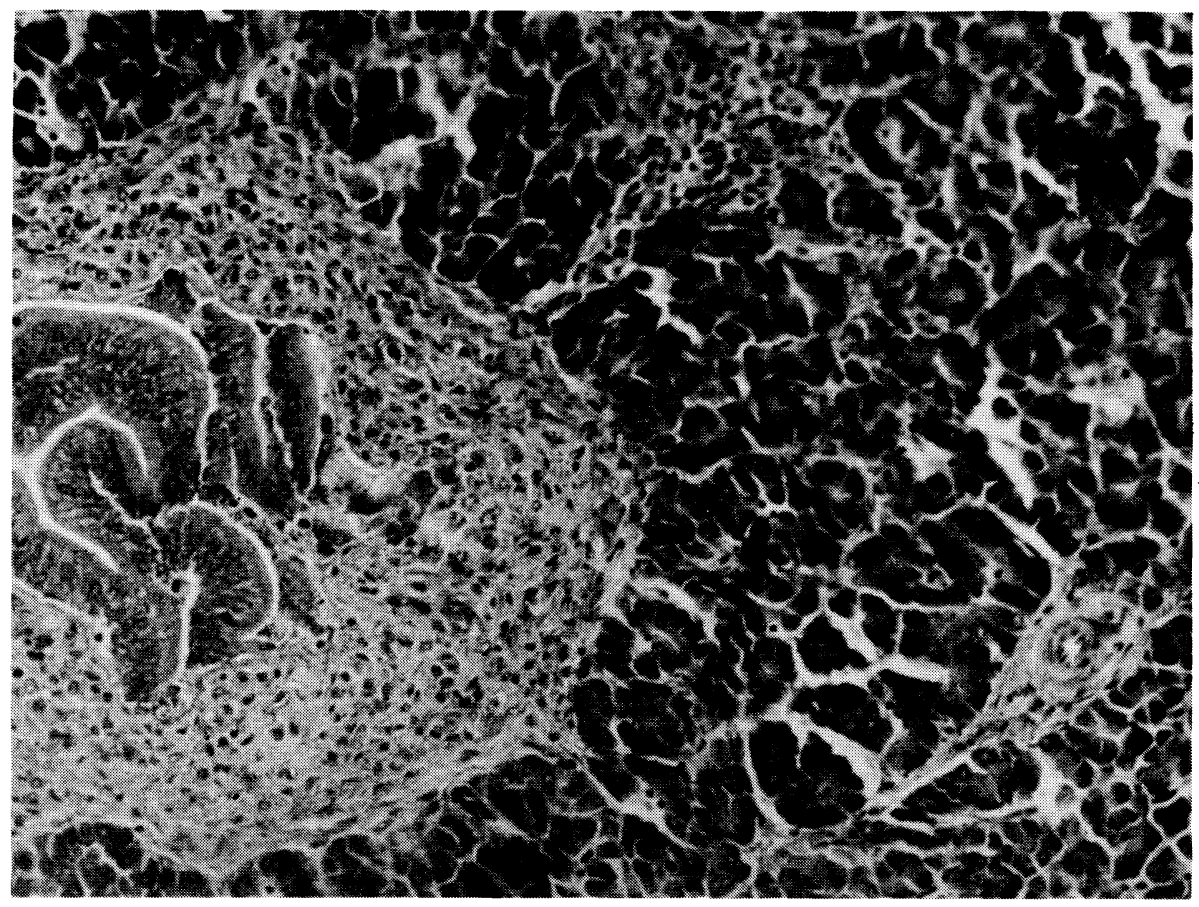

Fig. 3. Chronic inflammation of the pancreotic duct. HE: $\times 640$.

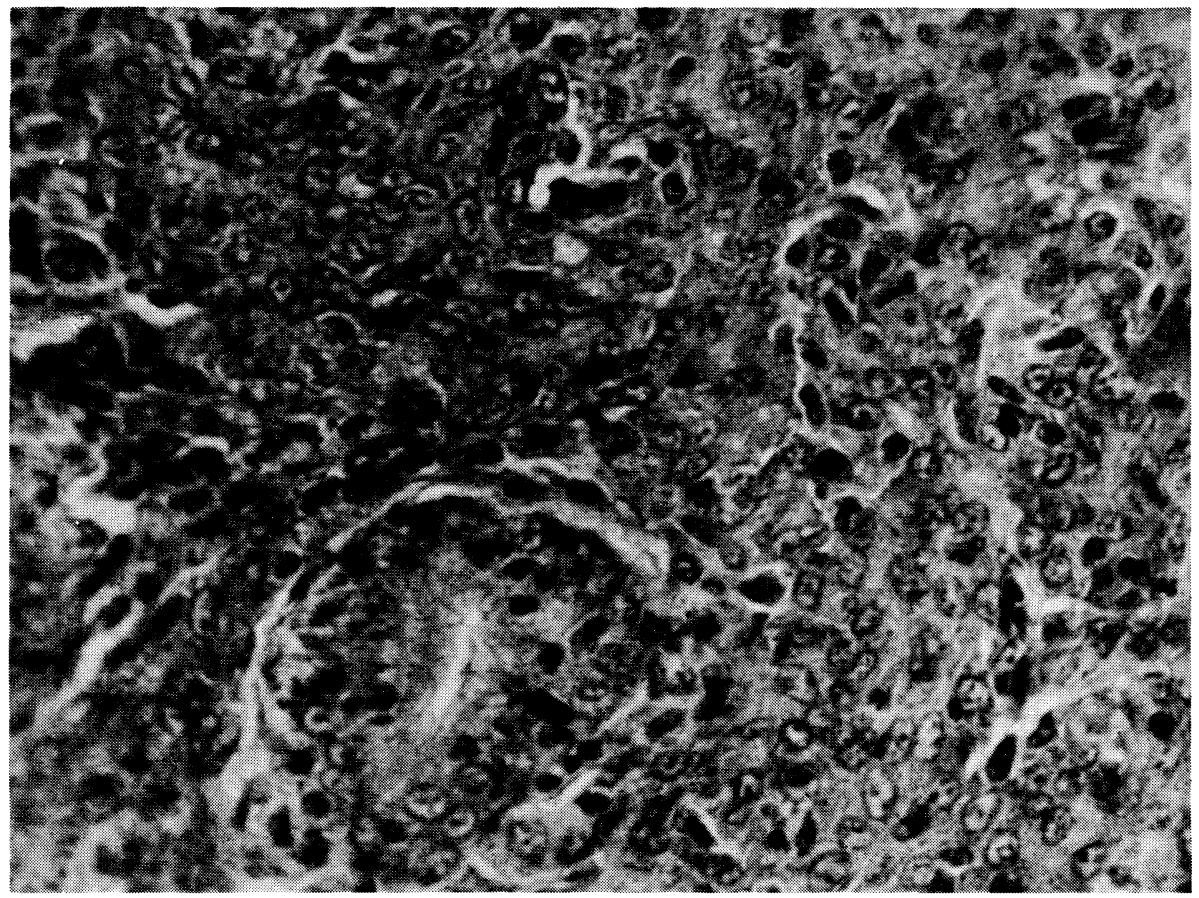

Fig. 4. Adenomatous proliferation of the exocrine portion of the pancreas. HE; $\times 640$. 


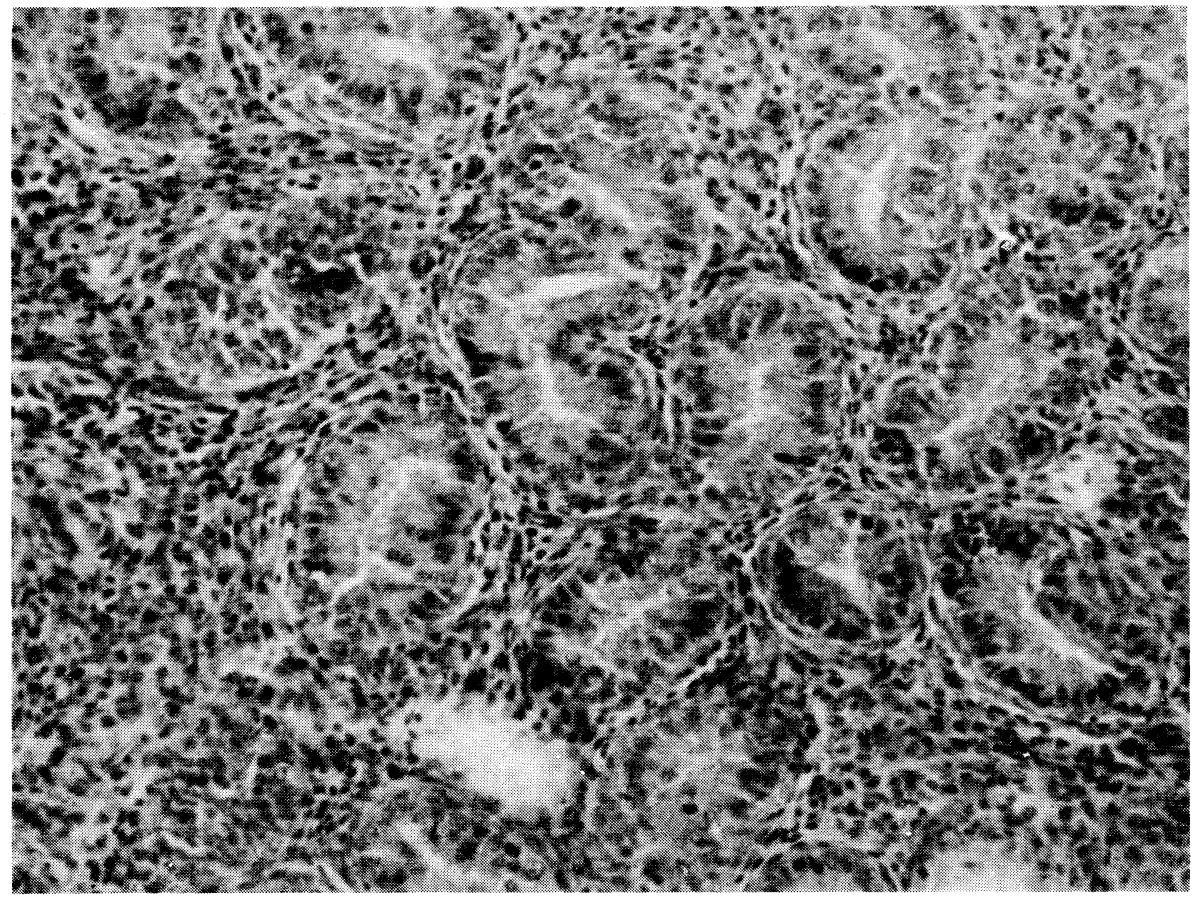

Fig. 5. Intertubular fibrosis of the testis. $\mathrm{HE} ; \times 640$.

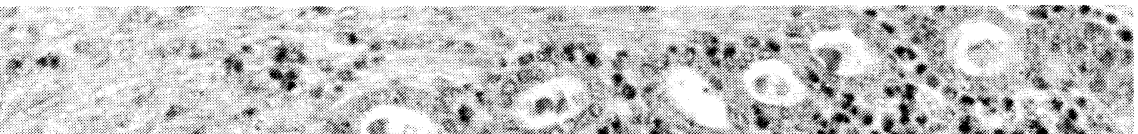

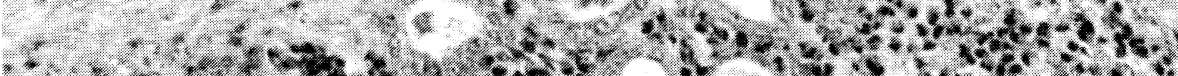

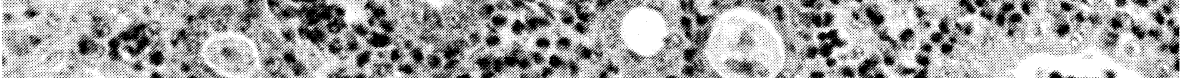

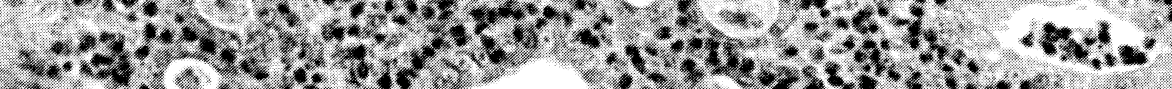

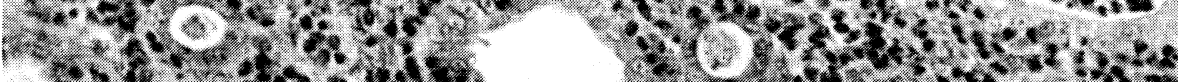

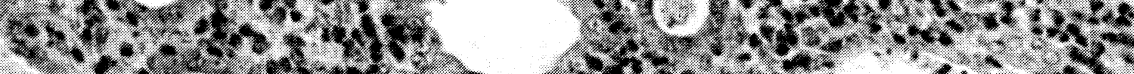
(1) 2.

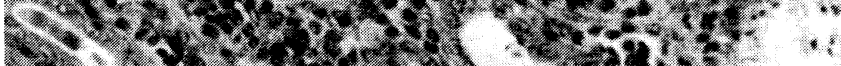
a.t.

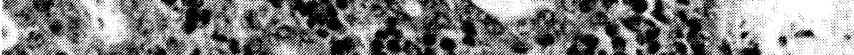

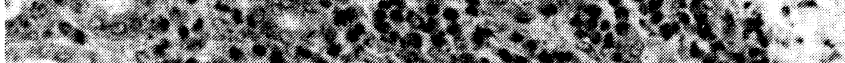

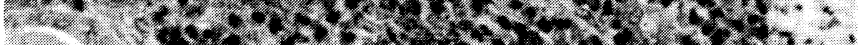
(1) - 2.t.

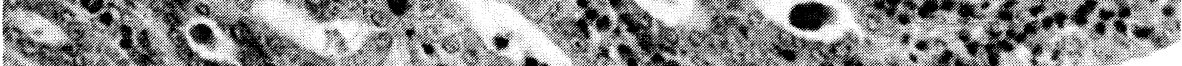

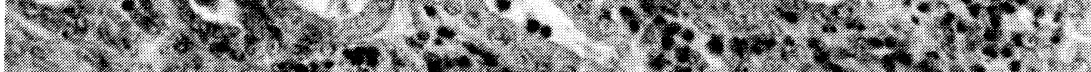

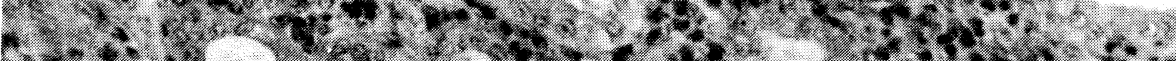

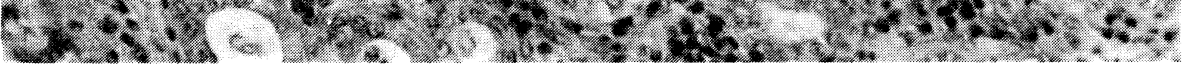

Fig. 6. Suppurative lesions in the kidney. HE; $\times 640$. 


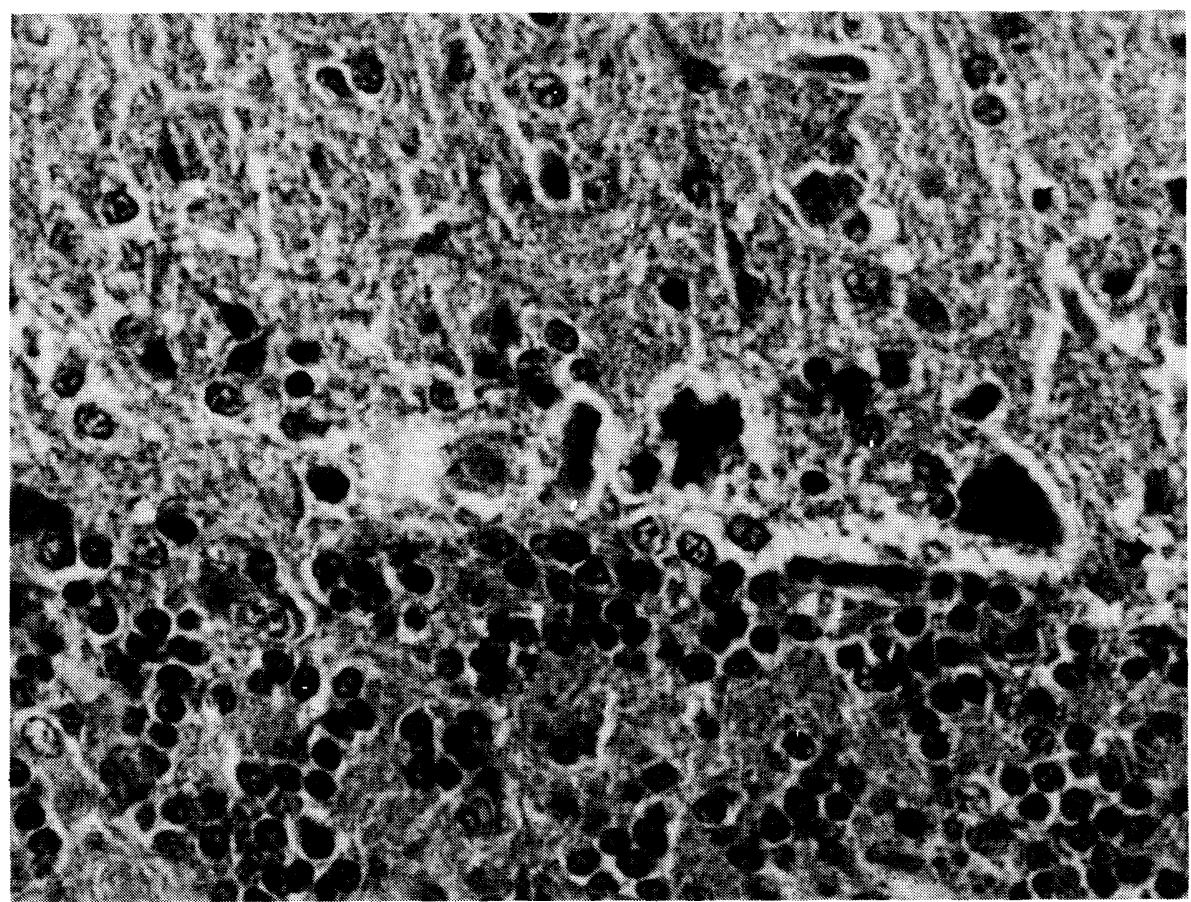

Fig. 7. Pycnosis of the nuclei of Purkinje cells in the cerebellum. HE; $\times 640$.

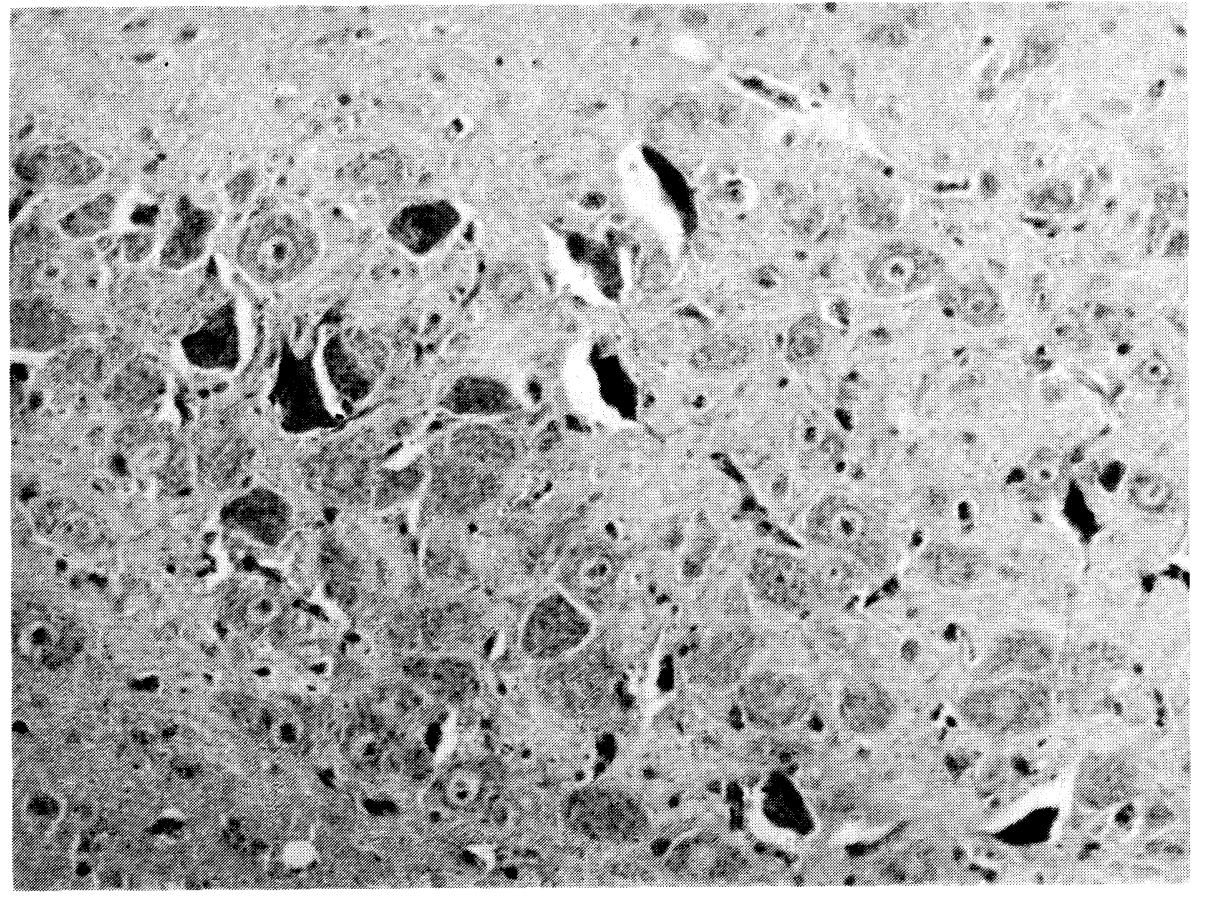

Fig. 8. Degenerative changes of neurons in the cerebellar nucleus. HE; $\times 640$. 